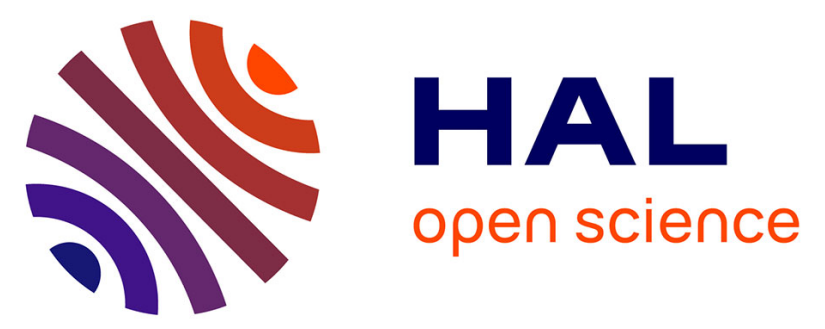

\title{
CYTOTOXIC ACTION OF GANODERMA LUCIDUM ON INTERLEUKIN-3 DEPENDENT LYMPHOMA DA-1 CELLS: INVOLVEMENT OF APOPTOSIS PROTEINS
}

Eva Calviño, Lucía Pajuelo, Jon A. Ochoa de Eribe Casas, José L. Manjón, María Cristina Tejedor, Angel Herráez, Manuel Díez Alonso, José C. Diez

\section{To cite this version:}

Eva Calviño, Lucía Pajuelo, Jon A. Ochoa de Eribe Casas, José L. Manjón, María Cristina Tejedor, et al.. CYTOTOXIC ACTION OF GANODERMA LUCIDUM ON INTERLEUKIN-3 DEPENDENT LYMPHOMA DA-1 CELLS: INVOLVEMENT OF APOPTOSIS PROTEINS. Phytotherapy Research, 2010, 25 (1), pp.25. 10.1002/ptr.3202 . hal-00599829

\section{HAL Id: hal-00599829 https://hal.science/hal-00599829}

Submitted on 11 Jun 2011

HAL is a multi-disciplinary open access archive for the deposit and dissemination of scientific research documents, whether they are published or not. The documents may come from teaching and research institutions in France or abroad, or from public or private research centers.
L'archive ouverte pluridisciplinaire HAL, est destinée au dépôt et à la diffusion de documents scientifiques de niveau recherche, publiés ou non, émanant des établissements d'enseignement et de recherche français ou étrangers, des laboratoires publics ou privés. 


\section{CYTOTOXIC ACTION OF GANODERMA LUCIDUM ON INTERLEUKIN-3 DEPENDENT LYMPHOMA DA-1 CELLS: INVOLVEMENT OF APOPTOSIS PROTEINS}

\begin{tabular}{|r|l|}
\hline Journal: & Phytotherapy Research \\
\hline Manuscript ID: & PTR-09-0859.R1 \\
\hline Wiley - Manuscript type: & Full Paper \\
\hline Date Submitted by the & 28-Jan-2010 \\
\hline Complete List of Authors: & $\begin{array}{l}\text { Calviño, Eva; Universidad de Alcalá, Dpto. Bioquímica y Biología } \\
\text { Molecular } \\
\text { Pajuelo, Lucía; Universidad de Alcalá, Dpto. Bioquímica y Biología } \\
\text { Molecular } \\
\text { Ochoa de Eribe Casas, Jon; Universidad de Alcalá, Dpto. Biología } \\
\text { Vegetal } \\
\text { Manjón, José; Universidad de Alcalá, Biología Vegetal } \\
\text { Tejedor, María; Universidad de Alcalá, Dpto. Bioquímica y Biología } \\
\text { Molecular } \\
\text { Herráez, Angel; Universidad de Alcalá, Dpto. Bioquímica y Biología } \\
\text { Molecular } \\
\text { Díez Alonso, Manuel; Hospital Universitario Príncipe de Asturias, } \\
\text { Servicio de Cirugía } \\
\text { Diez, José; Universidad de Alcalá, Dpto. Bioquímica y Biología } \\
\text { Molecular }\end{array}$ \\
\hline Keyword: & \begin{tabular}{l} 
Ganoderma, Lymphoma, Apoptosis \\
\hline \hline
\end{tabular} \\
\hline \hline
\end{tabular}

\section{今scholarONE" \\ Manuscript Central}


CYTOTOXIC ACTION OF GANODERMA LUCIDUM ON INTERLEUKIN-3

DEPENDENT LYMPHOMA DA-1 CELLS: INVOLVEMENT OF APOPTOSIS PROTEINS

\section{Eva Calviño ${ }^{\circ}$ Lucía Pajuelo $^{\circ}$ Jon A. Ochoa de Eribe Casas ${ }^{\star}$, José Luis Manjón , M. Cristina Tejedor ${ }^{\circ}$, Angel Herráez ${ }^{\circ}$, Manuel Díez Alonso \# and $\underline{\text { José C. Diez }}^{0 *}$}

o Departamento de Bioquímica y Biología Molecular. Campus Universitario. Universidad de Alcalá. 28871 Alcalá de Henares (Madrid) and • Departamento de Biología Vegetal. Campus Universitario. Universidad de Alcalá. 28871 Alcalá de Henares (Madrid) SPAIN. \# Servicio de Cirugía. Hospital Universitario Príncipe de Asturias. 28806 Alcalá de Henares (Madrid) SPAIN

Corresponding author: * José C. Diez. Departamento de Bioquímica y Biología Molecular. Campus Universitario. Universidad de Alcalá. 28871 Alcalá de Henares (Madrid) SPAIN.

Phone number: 34-91-8854582 or 34-91-8854579. Fax number: 34-91-8854585.

E-mail: josecarlos.diez@uah.es

Running title: Cytotoxicity of Ganoderma lucidum on lymphoma cells.

Key words: Bax, Bcl-2, Ganoderma lucidum (Curtis) P. Karst., Ganodermataceae Donk, Lymphoma, p53.

\section{Acknowledgments}

This work was supported in part by Grants from UAH PI2004/025, CAM-UAH 2005-040 and CCG06-UAH/SAL-0672. E. Calviño was supported by a "Miguel de Cervantes" fellowship from Universidad de Alcalá. We also want to thank the technical assistance of Isabel Trabado (C.A.I. Medicina-Biología. Unidad de Cultivos. Universidad de Alcalá) in cytometric analyses. 


\begin{abstract}
Aqueous extracts and a semipurified fraction obtained by methanol extraction and column chromatography were isolated from Ganoderma lucidum [Ganoderma lucidum (Curtis) P. Karst.; Ganodermataceae Donk] and their effects on interleukin 3-dependent lymphoma cells (DA-1) were studied. Cell viability was reduced by the action of unboiled aqueous extract and by the methanol-extracted column-chromatography semipurified fraction, producing DNA fragmentation in DA-1 cells. Treatments with aqueous extracts showed increments of Bax after 13 hours, increments of p53 and Mdm2 after 19 hours and reduction of these three proteins after 24 hours. Metanol-extracted semipurified fraction also induced increments of p53 and Mdm2 factors at 19 hours with reduction after 24 hours. The methanol-extracted column-chromatography semipurified fraction from Ganoderma lucidum produced minor changes in the level of Akt in treatments for 19 hours in DA-1 cells with slight reduction in the levels of NFkB-p65 factor. Both the unboiled aqueous extract and the methanol-extracted column-chromatography semipurified fraction produced cleavage of inactive caspase 3 , as a clear indication of induction of apoptosis by compounds present in Ganoderma lucidum.
\end{abstract}




\section{INTRODUCTION}

In recent times, a search for new therapeutic agents more effective and with more selective action on tumor cells is being conducted. The fungus Ganoderma lucidum (common names: Reishi, Lingzhi) is a well known mushroom in traditional Chinese medicine. Extracts from different parts (mycelia, spores and fruiting bodies) from Ganoderma lucidum have been used as a source of active compounds against tumor processes [Hu, 2002; Liu, 2002; Hong, 2004, Jiang, 2004b; Jiang, 2004a; Lu, 2004;; Sliva, 2004]. Among the different compounds present in Ganoderma lucidum, nucleosides, proteins, polysaccharides, fatty acids, sterols and triterpenes have been described as molecules which could be responsible for the antitumor activity [Yeung, 2004]. Ganoderma lucidum extracts inhibit growth of human prostate and bladder cancer cell lines [Jiang, 2004a; Lu, 2004] and cell proliferation inducing apoptosis in human colon carcinoma and breast cancer cell lines [Hu, 2002; Hong, 2004; Jiang, 2004b]. Polysaccharides present in Ganoderma lucidum may be responsible of growth delay of sarcoma cells [Cao, 2004]. In part, their antitumor activity may be a consequence of their immunomodulatory properties [Wilasrusmee, 2002; Williamson, 2001; Ling, 2005]. Also, triterpenes present in Ganoderma lucidum inhibit growth of hepatoma cells by altering intracellular phosphorylation pathways [Lin, 2003].

We have previously studied the apoptotic action of two antitumor compounds, etoposide and hydroxyurea, on DA-1 lymphoma cells [Olmos, 2005a; Olmos, 2005b] as a model for cytotoxicity by inducing apoptosis. These cells, derived from a murine lymphoma, could be sensitive to the action of antitumor and toxic compounds of therapeutical interest. Additionally, this model shows the advantage of being modulated by interleukin 3 [Gottlieb, 1994; Gottlieb, 1996; Gottlieb, 1998]. Thus, antiproliferative and apoptotic effects of antitumor compounds can be studied in this cell model. We have demonstrated the possible 
differential involvement of Bax and Bcl-2 factors in the apoptotic death of these cells after treatment with etoposide or hydroxyurea [Olmos, 2005a; Olmos, 2005b]. Thus, in the present work we have studied the cytotoxicity of different Ganoderma lucidum extracts, prepared as described by other authors [Sliva, 2002; Stanley, 2005] on these interleukin 3 dependent lymphoma cells. Aqueous extracts and a methanol-extracted semipurified fraction from Ganoderma lucidum demonstrated ability to reduce cell viability in DA-1 cells and also induced DNA fragmentation. Changes in protein expression of apoptosis factors were also observed after treatments with these extracts showing activation of apoptosis cascades.

Some authors have previously shown the activation of intracellular kinase cascades by Ganoderma extracts in induced neuronal differentiation in rat PC12 cells [Cheung, 2000]. Jiang, 2004b also showed inhibition of Akt/NF-kB signalling by Ganoderma lucidum in breast cancer cells. Thus, we have also focused our interest on activation and phosphorylation of intracellular kinases which are altered in other cellular model systems [Jiang, 2004b, Cheung, 2000]. Changes in expression and phosphorylation of Akt have been studied after treatment of DA-1 cells with aqueous extracts and the methanol-extracted semipurified fraction from Ganoderma lucidum. 


\section{MATERIALS AND METHODS}

\section{Cell lines}

Two cell lines were used:

Mouse interleukin 3 dependent lymphoma DA-1 cells were kept at $37^{\circ} \mathrm{C}$ and $5 \% \mathrm{CO}_{2}$, in Iscove's MDM medium containing $10 \%$ foetal calf serum, $2 \mathrm{mM}$ L-glutamine and $2.5 \times 10^{-5}$ M $\beta$-mercaptoethanol.

WEHI-3B cell line was employed and applied as a source of conditioned medium containing interleukin 3, which is required for the survival of DA-1 cells. The supernatant containing the medium with secreted IL-3 was obtained by centrifugation at $1200 \mathrm{x} \mathrm{g}$ for $5 \mathrm{~min}$ and subsequent filtration. DA-1 cells were grown in the presence of $5 \%$ of this conditioned medium.

\section{Source of Ganoderma lucidum}

Ganoderma lucidum [Ganoderma lucidum (Curtis) P. Karst.; Ganodermataceae Donk] strain was isolated from the fruit body tissue (context) of a wood-inhabiting filamentous parasitic fungi growing in a natural habitat on Quercus ilex roots in Cáceres (Spain). A small part of the tissue context developed Ganoderma lucidum mycelium that was cultured and subcultured in a Malt extract solid medium (MA). In order to produce fruiting bodies it was necessary to cultivate the fungus on lignocellulosic solid medium substrate (Chang \& Miles, 2004), adequately hydrated and autoclaved. Once the lignocellulosic medium was inoculated with $G$. lucidum mycelia, the substrate was incubated until a proper mycelial colonization. Subsequently, the bulk mycelium developped fruit bodies that reached maturity in 1-2 months.

\section{Extracts of Ganoderma lucidum}

Fruiting bodies of G. lucidum were resuspended in sterile water to a concentration of 50 $\mathrm{mg} / \mathrm{ml}$ [Sliva, 2002; Stanley, 2005], homogenized and then centrifuged at 14,000 rpm (in a 
Beckman J2.21 centrifuge using JA-20.1 rotor) for $5 \mathrm{~min}$, at room temperature, to obtain a supernatant called extract 1 (E1). The pellet was resuspended in the same volume of sterile water, boiled for $5 \mathrm{~min}$, sonicated for 20 seconds at 50\% intensity, centrifuged at 14,000 rpm for $5 \mathrm{~min}$ and the supernatant obtained was called extract 2 (E2). Afterwards, these extracts were lyophylized and disolved in 1/10 the initial volume, giving ten-fold concentrated extracts.

Methanolic extracts of G. lucidum were also obtained. Fruiting bodies ( $2 \mathrm{~g}$ ) were disrupted with liquid nitrogen and the resulting material was resuspended at $50 \mathrm{mg} / \mathrm{ml}$ concentration in $10 \%$ methanol and extracted three times with $10 \%$ methanol for $24 \mathrm{~h}$ with agitation. The combined extracts were evaporated to drynewss in a rotary evaporator, and dissolved in absolute methanol. To purify this extract, it was adsorbed on $0,2 \mathrm{~g}$ of silicagel to be applied onto a silica gel column $(1 \times 15.5 \mathrm{~cm})$ and subsequently eluted with 3:1:1 butanol: acetic acid: water. Column fractions $(0.2 \mathrm{ml})$ with an Rf near 0.74 were combined, the solvent was evaporated and the final sample $(1.6 \mathrm{mg}$ ) was resuspended in $0,01 \mathrm{ml}$ DMSO to obtain the extract $3(\mathrm{E} 3)$.

We have used aqueous extracts E1 and E2 prepared as described by other authors. It is highly probable that sugars are present in these extracts. Several polysaccharides present in $G$. lucidum have been shown to have immunomodulatory and antitumor activities [Cao \& Lin, 2006; Sliva et al., 2002; Stanley et al., 2005]. With respect to the E3 fraction, isolated in column chromatography from a methanolic extract of G. lucidum, based on the solvents used it may be possible that compounds similar to terpenoids could be present in this fraction [Li et al., 2005; Lin et al., 2003; Min et al. 2000].

\section{Cell treatments}

Cultured DA-1 cells were incubated at concentrations of $0,5 \times 10^{6}$ cells $/ \mathrm{ml}$ at $37^{\circ} \mathrm{C}$ in an atmosphere with $5 \% \mathrm{CO}_{2}$ in the presence of IL-3 conditioned medium. DA-1 cells were 
grown in the presence of IL-3 conditioned medium alone or supplemented with either Ganoderma lucidum extracts or $100 \mu \mathrm{M}$ etoposide as a positive control for toxicity and apoptosis induction.

E1 and E2 extracts and E3 fraction were added separately to $1 \mathrm{ml}$ aliquots of cell culture ( 0.5 x $10^{6}$ cell/ml) and allowed to act for 13,19 and 24 hours.

Lyophylized E1 extract (14.9 mg dried weight) was dissolved in $0.9 \mathrm{ml}$ of sterile distilled water and $60 \mu \mathrm{l}$ were added per $\mathrm{ml}$ of cell culture.

Lyophylized E2 extract (3 mg dried weight) was dissolved in $0.9 \mathrm{ml}$ of sterile distilled water and $60 \mu 1$ were added per $\mathrm{ml}$ of cell culture.

Fraction 3 (E3) $(2.08 \mathrm{mg}$ ) dissolved in $13 \mu \mathrm{l}$ of DMSO was added per $\mathrm{ml}$ of cell culture $(0.5 \mathrm{x}$ $\left.10^{6} \mathrm{cell} / \mathrm{ml}\right)$.

DMSO (13 $\mu \mathrm{l})$ was also added to cells as a negative control and no toxic effect was observed on cell culture (i.e. no reduction of cell viability, no DNA fragmentation, etc.).

\section{Cell viability, permeability of treated cells to propidium iodide and flow cytometry analyses}

Cell viability of DA-1 cells incubated in the presence of IL-3 and treated with Ganoderma lucidum extracts was determined by flow cytometry by measuring the impermeability to propidium iodide. $2.5 \times 10^{5}$ treated cells were collected, washed in PBS, pelleted at 1,200 rpm for $5 \mathrm{~min}$, resuspended in $500 \mu \mathrm{l}$ of PBS and stained with propidium iodide at $5 \mu \mathrm{g} / \mathrm{ml}$ final concentration and, analyzed by flow cytometry either in FACScan or FACScalibur (Becton Dickinson, San José, CA, USA). For each sample the acquisition was finished at 10.000 counts. Data analysis was done using the program Win-MDI (Windows Multiple Document Interface for Flow Cytometry, version 2.8, available from Scripps Research Institute, FACS Core Facility, http://facs.scripps.edu/software.html) [Trotter, 2004]. Cell fragments were discriminated from the non viable cells on FSC/FL-2-H dot plots, where FL-2-H corresponds to propidium iodide fluorescence. 


\section{Cytometric analysis of cell populations with subdiploid DNA and cell cycle}

Apoptotic cells were counted on the basis of DNA content per cell after permeabilization of cells with NP40. After treatments with $100 \mu \mathrm{M}$ etoposide or G. lucidum extracts, $2.5 \times 10^{5}$ cells were collected and washed with PBS. The pellet was resuspended in $475 \mu 1$ of a solution containing $0.5 \mathrm{mg} / \mathrm{ml}$ RNase, $0.1 \%$ of NP-40 in PBS and incubated for $30 \mathrm{~min}$ in order to extract low molecular weight DNA from cell nuclei. The remnant DNA in cells was stained with $0.05 \mathrm{mg} / \mathrm{ml}$ propidium iodide, immediately before measuring the fluorescence in the cytometer.

Cells with hypodiploid DNA (apoptotic cells) were distinguished from those containing diploid DNA (non apoptotic cells) on the basis of a different fluorescence intensity of propidium iodide in flow cytometer. Cell cycle progress was studied in the same samples. Histograms of the untreated cells were used to define the positions of the different peaks for the $\mathrm{G} 1$ and $\mathrm{G} 2 / \mathrm{M}$ phases in the cell cycle.

\section{Western blot}

$5 \times 10^{6}$ cells treated with the extracts during 13,19 or 24 hours were collected by centrifugation at 1,200 rpm for $5 \mathrm{~min}$, resuspended in $200 \mu \mathrm{l}$ of lysis buffer (50 mM Tris/HCl pH 8.0, $150 \mathrm{mM} \mathrm{NaCl} ; 5 \mathrm{mM}$ EDTA; $0.5 \%$ NP-40; $1 \mathrm{mM}$ PMSF) and incubated for $20 \mathrm{~min}$ at $4^{\circ} \mathrm{C}$. Cells were sonicated for $20 \mathrm{~s}$ (duty cycle $100 \%$, output control 50\%) in a Branson Cell Disruptor B15 Sonifier and then centrifuged $\left(14,000 \mathrm{rpm}, 5 \mathrm{~min}, 4^{\circ} \mathrm{C}\right)$ and the supernatants were analyzed by electrophoresis and blotting. Proteins ( $20 \mu \mathrm{g} /$ well) were loaded on a $10 \%$ polyacrylamide gel with SDS, electrophoretically separated and transferred to nitrocellulose membranes as described [Towbin, 1979]. Membranes were blocked with 5\% powder milk in TTBS (50 mM Tris $\mathrm{pH} 7.2,140 \mathrm{mM} \mathrm{NaCl}, 0.06 \%$ Tween 20). Afterwards, 
they were washed with TTBS and incubated with antibodies specific against several apoptosis factors diluted in TTBS containing milk.

All the following antibodies were obtained from Santa Cruz Biotechnology, CA, USA, and used at the dilution indicated: Anti-Bax mouse monoclonal $\operatorname{IgG}_{2 b}(B-9 ; s c-7480 ; 200 \mu \mathrm{g} / \mathrm{ml})$ 1:100; anti-Bcl-2 mouse monoclonal $\operatorname{IgG}_{1}$ antibody (C-2; sc7382; $\left.200 \mu \mathrm{g} / \mathrm{ml}\right) 1: 200$; antiMDM2 (SMP14) 1:100; anti-Akt1/2/3 (H-136) sc-8312 antibodies, 1:400; anti-pAkt1/2/3 (Ser 437) sc-7985-R antibodies 1:400; anti Erk1/2 sc-154 antibodies 1:3000; anti p-Erk1/2 (Tyr $\left.{ }^{204}\right)$ sc-7383 antibodies 1:200; anti-NFkB p50 and p105 (EA0) sc-8414 antibodies 1:200; antiNFkB p65 (F-6) sc-8008 antibodies 1:200.

Anti-p53 mouse monoclonal IgG antibody (Ab-1, OP03; $100 \mu \mathrm{g} / \mathrm{ml}$ ) was purchased from Calbiochem (Oncogene Research Products, MA, USA) and diluted 1:50.

Monoclonal anti- $\beta$-actin antibodies were purchased from Sigma A5441 and used at a dilution of 1:5000.

Polyclonal caspase 3 antibodies were purchased from Cell Signalling Technology (Reference number 9662) and used at a dilution of 1:1000.

After incubation of the nitrocellulose membranes with specific antibodies overnight at $4^{\circ} \mathrm{C}$ the bands were revealed using goat anti-mouse horseradish peroxidase-conjugated polyclonal antibodies (1:2000) from Promega (Madison, WI) in an enhanced chemiluminescence (ECL) detection kit (Amersham). The intensities of the bands were corrected with respect to the intensity of actin band in the blot, as a control for constitutive expression, and quantified relative to the intensity of the band in control cells without any treatment, which were considered as $100 \%$.

All the experiments were repeated three or four times. The mean and SEM were graphically represented. In order to determine the significance of the effect, Student's t test was used. The asterisk $*$ indicates $\mathrm{p}<0,05$. 


\section{RESULTS}

\section{Cell viability analyses of $\mathrm{DA}-1$ cells}

Cell viability of DA-1 lymphoma cells was determined after treatment with Ganoderma lucidum extracts obtained as described in Methods. As can be observed, etoposide (Figure 1) at concentrations of $100 \mu \mathrm{M}$ induced a decrease in cell viability, with values of 70,58 and $51 \%$ viability in cells treated with etoposide for 13, 19 and 24 hours. Also, different extracts obtained from Ganoderma lucidum were used: Both E1 and E3 show an effective reduction in cell viability with reduction of up to 70 and $36 \%$ at 24 hours of treatment, respectively (Figure 1). On the contrary, E2 extract shows not so clear action on viability. In the case of E1 the effects are clearly visible after 19 hours. E3 showed an even more effective action than E1 extract (Figure 1). Thus, the analyses of cell viability clearly demonstrate the action of these extracts (E1 and E3) on cell membrane permeability which allows the entrance of propidium iodide.

Figure 2 shows some representative diagrams where it is possible to observe the increment in the peak corresponding to cells permeant to propidium iodide due to the alteration of the membrane (see the increased peak of higher fluorescence in FL2-H in samples treated with Ganoderma lucidum extracts). The toxic action of E3 is more clearly visible than that of E1 both at 13 and 24 hours.

\section{Cell death induction in DA-1 cells}

Previously, we have shown that either of two antitumor compounds (hydroxyurea or etoposide) induces apoptosis in DA-1 cells [Olmos, 2005a; Olmos, 2005b], as tested by permeability alteration analyses, DNA fragmentation and annexin-FITC studies. The apoptotic action of these compounds can be related to changes in cell cycle. Thus, we studied the effects on cell cycle as well as on the presence of subdiploid DNA. In figure 3, we show the results obtained for treatments of DA-1 cells in the presence of the extracts obtained from 
Ganoderma lucidum. As it can be observed, E1 extract showed a level of cell death induction (as tested by production of subdiploid DNA) similar to that of $100 \mu \mathrm{M}$ etoposide. At 24 hours, the induction of subdiploid DNA was even higher in the case of E1 than etoposide. E3 fraction showed too an important induction of subdiploid DNA in DA-1 cells, an effect that is more clearly visible at 24 hours. On the contrary, E2 extract showed a very limited induction of cell death in DA-1 cells even at 24 hours. Figure 4 shows representative diagrams of DNA content of control and E1 and E3 treated DA-1 cells. The effects of E1 extract are clearly visible at 24 hours (with an important peak corresponding to subdiploid DNA) although they are already apparent at 13 hours. Methanol-extracted semipurified E3 fraction also induced DNA fragmentation (see the panels on the right side of Figure 4). In this case, it is possible to observe a prominent peak with high fluorescence in FL2-H at 13 and 24 hours, that might indicate an arrest in $\mathrm{S}$ phase of the cell cycle as a consequent of the treatment.

\section{Analyses of expression of apoptosis related factors}

Since some factors such as p53, Bax, Bcl-2 and Mdm-2 are involved in apoptosis processes, we have analysed the levels of these proteins (Figures 5, 6, 7 and 8) by Western-blot using specific antibodies.

Figure 5 shows representative plots corresponding to the Western-blot analyses of DA-1 cells treated with E1 extract. p53 expression is reduced with respect to control in cells after 13 hours of treatment with E1, an effect which later reverts reaching $160 \%$ at 19 hours of treatment (Figures 5 and 8). Bax protein increases earlier, doubling the levels of control at 13 and for 19 hours of treatment with E1. Analysis of Bcl-2 expression reveals a decrease at 13 hours. Longer treatments (19 and 24 hours) recover the level to values similar to untreated cells. Mdm2 showed also a clear reduction at 13 hours and an increase at 19 hours with restoration of the level at 24 hours to those found in control cells (Figure 5). 
The effect of E2 extract is shown in Figure 6. At 13 hours, treated DA-1 cells showed increments in Bax and Mdm2, while Bcl-2 showed a reduction. In the case of Mdm2, a high level of this protein was observed also at treatments for 19 hours.

Figure 7 shows the response to E3 fraction. Increments in p53, Mdm and Bcl-2 were observed after treatment for 19 hours (see also Figure 8).

We also checked variations in the expression of some other factors such as the kinases Akt and NFkB (Figures 5, 6, 7 and 8).

Akt was increased after 19 or 24 hours treatment with E1 extract (Figures 5 and 8) while NFkB was reduced at 13 hours of E1 treatment (Figure 5).

In the case of E2 treatments, minor variations in Akt and slight increments of pAkt were observed as time passed by (Figures 6 and 8 ) and NFkB showed values of $80 \%$ of control at all time points (Figure 6).

After treatment of DA-1 cells with E3 fraction, the levels of Akt remain close to controls after 13 hours, with a slight increase at 19 hours and then a decrease. Its phosphorylated form pAkt remains nearly constant through the treatment although lower than in untreated cells $(61 \%, 60 \%$ and $65 \%$ at 13, 19 and 24 hours, respectively) (Figures 7 and 8). NFkB was reduced by E3 treatment (Figure 7).

To further confirm an apoptosis effect induced by either of these extracts we quantitated uncleaved caspase 3 in DA-1 treated cells in comparison to untreated cells (Figure 9). As it can be observed, both E1 extract and semipurified E3 fraction produced a clear reduction of inactive caspase 3 in Western-blots analyses (Figure 9), and effect clearly visible at 24 hours. To the contrary, no effect was manifested by treatment with E2. 


\section{DISCUSSION}

Antitumor compounds can exert toxic effects on different kinds of cells and induce apoptosis in tumor cells. Ganoderma lucidum is a mushroom with components that have been claimed to show antitumor properties. Some authors have shown inhibition of the growth of solid tumors of sarcoma by using aqueous extracts from G. lucidum [Sone, 1985]. For instance, Xie, 2006 observed significant changes in the induction of cell death in breast cancer and lymphoma cells alter treatment with a polysaccharide extract from G. lucidum. In contrast, Sliva, 2002 or Jiang, 2004b in breast and prostate cancer cells, Cao, 2004 in endotelial cells and Müller, 2006 in different lymphoma cell lines did not observe significant changes in cell viability alter treatment with different extracts from G. lucidum.

On the basis of previous studies [Gottlieb, 1994; Gottlieb, 1996; Gottlieb, 1998; Olmos, 2005a; Olmos, 2005b], we have studied the activity of aqueous and alcoholic Ganoderma lucidum extracts on DA-1 lymphoma cells. A reduction in viability was observed after treatment with an unboiled aqueous extract (E1) that was obtained similarly to that described by others [Sliva, 2002; Stanley, 2005] (Figs. 1 and 2). Thus, aqueous extraction from Ganoderma lucidum renders some compounds with toxicity on DA-1 lymphoma cells (Figs. 1 and 2). E3 fraction also showed toxic effects on lymphoma cells reducing cell viability up to 36\% (Figs. 1 and 2). These results are in accordance with those results described by other authors [Lin, 2005] that showed inhibition of cell growth in liver cancer cells (Huh-7) after treatment with alcohol extracts from G. lucidum.

Our results shown in this work (Figures 3 and 4) indicate that E1 extract and E3 fraction induced fragmentation of DNA, measured as subdiploid DNA. These data are similar to those described by Jiang, 2004a who showed programmed cell death induced by G. lucidum in prostate cancer PC-3 cells and by Cao, 2004 who described the apoptosis induction in endotelial cells from umbilical cord by a polysaccharidic extract from G. lucidum. Müller, 
2006 also described apoptosis in lymphoma cells induced by methanolic extract from $G$. lucidum containing $\mathrm{C} 2$ ganoderic acid. Our data are also in accordance to that described by $\mathrm{Hu}, 2002$ who showed inhibition of the proliferation of breast cancer MCF-7 in a timedependent way and induction of apoptosis after treatment with an alcoholic extract from $G$. lucidum. Our results may also be compared to those described by Tang, 2006 who studied the action of $\mathrm{T}$ ganoderic Acid in lung cancer 95-D cells finding induction of apoptosis in a timedependent way. Li, 2005 also observed induction of apoptosis in human cancer HuH-7 cells by triterpenes from Ganoderma amboinense, in particular by $\mathrm{X}$ ganoderic acid with inhibition of topoisomerases, what can be correlated to the presence of cytotoxic compounds in Ganoderma sp.

In the present work, we have checked whether the observed cell death may be mediated by changes in apoptosis factors. p53 is known to play an essential role in apoptosis induced by some antitumor compounds [Lowe, 1994; Newcomb, 1995]. In some cell types, p53 is actually required for an apoptotic response [Messmer, 1997; Palacios, 2000]. p53 has been identified in many cases as an initiator of apoptotic signals [Merino, 1998] being a regulator of cell cycle progression and a mediator of apoptosis in response to DNA damage. Tang, 2006 observed an increase in p53 levels in lung cancer 95-D cells alter treatment with $\mathrm{T}$ ganoderic acid assuming that this activation of p53 could be stimulated by DNA damage induced by this compound [Li, 2005]. Cerebrosides isolated from G. lucidum inhibited DNA polymerases and induced DNA damage [Mizushina, 1998]. In the present study, treatments of DA-1 cells with E1 or E3 fraction produced increments in p53 levels after 19 and 24 hours (Figs. 5-7), particularly for E3. Thus, this protein might be involved on cell death induced in DA-1 lymphoma cells by G. lucidum (Figs. 5, 6 and 7). In contrast, the modulation of p53 by E2 extract is quite modest. 
p53 regulates the expresión of Mdm2 and Bcl-2 [Barak, 1993] both of which inhibit the apoptosis mediated by p53 [Chiu, 1994; Chen, 1996]. In the case of Mdm2, the pattern of expression showed a reduction for E1 and E3 treatments at 13 hours. One common factor between E1 and E3 appears to be the up/down-regulation of p53/Mdm2 whereas this was not the case for E2 extract.

p53 could also regulate the expression of bax [Miyashita, 1995], which promotes cell death [Allen, 1998]. We observe a reduction of Bcl-2 levels in DA-1 cells after treatment for 13 hours with E1 or E2 extracts or E3 fraction from Ganoderma lucidum (Figs. 5 and 7). Cao, 2004 also observed a reduction of the levels of Bcl-2 and an increment of the levels of Bax, in HUVEC cells treated with polysaccharides from G. lucidum. Tang, 2006 found that Bax expression increased in lung cancer 95-D cells after treatment with $\mathrm{T}$ ganoderic acid maintaining the levels of Bcl-2. These authors suggested apoptosis induction by $\mathrm{T}$ ganoderic acid via alteration of the Bax/Bcl-2 ratio. Jiang, 2004 found that an aqueous extract containing polysaccharides and triterpenes from G. lucidum reduced the expression of Bcl-2 in prostate cancer PC-3 cells and increased the levels of Bax, correlating changes in Bax/Bcl-2 ratio with apoptosis induction [Raisova, 1998]. The increase of Bax in cells treated for 13 hours with Ganoderma lucidum E1 or E2 extract could suggest a role of Bax in the apoptosis induced by this extracts (Figures 5 and 6). In the case of E3 fraction (Figure 7), Bax disminished slightly with respect to untreated cells while Bcl-2 increased, showing low values for Bax/Bcl-2 ratio which could be characteristic of resistant cells.

$\mathrm{NF}-\mathrm{kB}$ is a factor related to cell growth, survival, angiogenesis, adhesion and migration [Mayo, 2000; Shibata, 2002]. Jiang, 2004b studied the effect of an aqueous extract containing polysaccharides and triterpenes from G. lucidum in MDA-MB-231 breast cancer cells showing inhibition of NF-kB. A similar result has been described in PC-3 prostate cancer cells [Jiang, 2004a]. In cultures of rat cortical neurons exposed to hypoxia, Zhao, 2004 also 
observed blockage in activation of NF-kB as a consequence of a polysaccharidic extract from G. lucidum. From our results it can be inferred an inhibition of NF-кB, since E1, E2 or E3 reduced the levels of NF-kB in DA-1 cells (Figures 5-7).

Jiang, 2004b studied the implication of Akt on the inhibitory effect of an aqueous extract containing polysaccharides and triterpenes from G. lucidum on NF-kB in MDA-MB-231 cells finding an inhibition of Akt expression in a dose- and time-dependent way. Although they did not find a reduction in phosphorylation of Akt (pAkt) in $\mathrm{Thr}^{308}$, they observed a reduction in the levels of pAkt Ser ${ }^{473}$. Stanley, 2005 carried out a similar study in PC-3 cells, finding no changes either in Akt expression or in its phosphorylation in $\mathrm{Thr}^{308}$. Anyhow the levels of pAkt in $\operatorname{Ser}^{473}$ disminished in a dose-dependent response. Our results show that independent treatments with any of the extracts or E3 fraction from G. lucidum slightly increased the levels of Akt at 19 hours. In the case of E1 extract and E3 fraction (Figures 5, 7 and 8) the levels of Akt decreased at 24 hours in accordance to Jiang, 2004a and b who carried out longer treatments (up to 96 hours). E1 extract treatment also produced a very slight reduction of pAkt in treatment for 24 hours what could correlate to that showed by Jiang, 2004 a and b. Stanley, 2005 also showed a reduction of the level of p-Akt-Ser ${ }^{473}$ in treatments for 24 hours with different doses of an aqueous extract from Ganoderma lucidum containing polysaccharides and triterpenes. E2 extract induced a reduction of Akt and pAkt $\operatorname{Ser}^{473}$ at 13 hours (Figures 6 and 8) with an increase of Akt at longer times. The correlation of the effects of E1, E2 extracts or E3 fraction on cell viability and DNA fragmentation in DA-1 cells (Figures 1 and 3) with the involvement of Akt expression and its phosphorylation on the cytotoxic action of Ganoderma lucidum in DA-1 cells can not be yet clearly established.

Finally, apoptosis induction by either E1 extract or E3 fraction on DA-1 cells was clearly confirmed since caspase 3 activation was stimulated (Figure 9). Cleavage of inactive caspase 
3 demonstrates the role of the apoptosis mechanism in the cytotoxicity induced in DA-1 cells by E1 extract or E3 fraction from Ganoderma lucidum. 


\section{LEGENDS TO FIGURES}

Figure 1. Cell viability of DA-1 cells grown in different culture conditions.

DA-1 cells were grown in the conditions indicated in Experimental section in the presence of conditioned medium containing interleukin 3, E1, E2 or E3 represent treatments with Ganoderma lucidum extracts. Etoposide $100 \mu \mathrm{M}$ treatment was used as a control. Different times of treatment are shown by open, filled and striped bars. All the experiments were repeated three or four times and the mean and SEM are plotted. Significance was evaluated using student's $\mathrm{t}$ test. The asterisk $*$ indicate $\mathrm{p}<0.05$.

Figure 2. Propidium iodide permeability of DA-1 cells grown in different culture conditions. Cellular viability was measured through propidium iodide permeability. Representative histograms of propidium iodide fluorescence are shown for control cells and cells treated either with $100 \mu \mathrm{M}$ etoposide, E1 extract or E3 fraction from Ganoderma lucidum.

Figure 3. Apoptosis of DA-1 cells induced by extracts from Ganoderma lucidum. The apoptosis induced by treatment with extracts from Ganoderma lucidum was measured by quantifying subdiploid DNA. Different times (13, 19 and 24 hours) are shown by open, filled and striped bars. Untreated cells and cells treated with $100 \mu \mathrm{M}$ etoposide are included as negative and positive controls for apoptosis. All the experiments were repeated three or four times and the mean and SEM are plotted. Significance was evaluated using student's t test. The asterisk $*$ indicate $\mathrm{p}<0.05$.

Figure 4. DNA fragmentation on DA-1 cells induced by treatments with different extracts from Ganoderma lucidum. The apoptosis induced by treatment with extracts from 
Ganoderma lucidum was measured by quantitation of subdiploid DNA. This figure shows representative histograms of the DNA content, measured with propidium iodide, present in control cells and cells treated with $100 \mu \mathrm{M}$ etoposide, E1 extract or E3 fraction from Ganoderma lucidum after 13 or 24 hours. The number of events versus the intensity of fluorescence of propidium iodide is shown.

\section{Figure 5. Expression of apoptotic factors in DA-1 cells treated with E1 aqueous extract.}

DA-1 cells were incubated with E1 and Western blots of proapoptotic and antiapoptotic

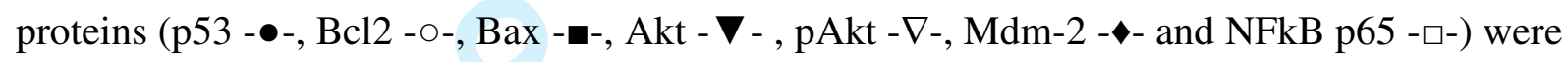
carried out. Control represents untreated cells. Actin was used as a control of constitutive expression. Treatments were applied for 13, 19 and 24 hours. The represented values correspond to the mean of three different experiments. All values were corrected to the staining intensity of actin in control cells.

Figure 6. Expression analyses of DA-1 cells levels of apoptotic factors in DA-1 cells treated with E2 aqueous extract. DA-1 cells were incubated with E2 and Western blots of

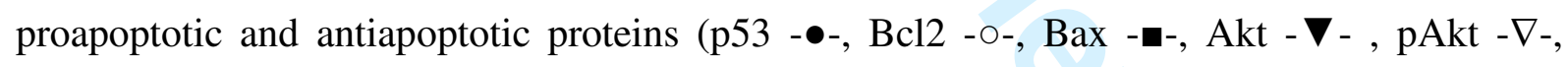
Mdm-2 - - and NFkB p65 - $\square-)$ were carried out. Control represents untreated cells. Actin was used as a protein control of constitutive expression. Treatments were applied for 13, 19 and 24 hours. The represented values correspond to the mean of three different experiments. All values were corrected to the staining intensity of actin in control cells.

Figure 7. Expression analyses of DA-1 cells levels of apoptotic factors in DA-1 cells treated with methanol-extracted semipurified E3 fraction. DA-1 cells were incubated with

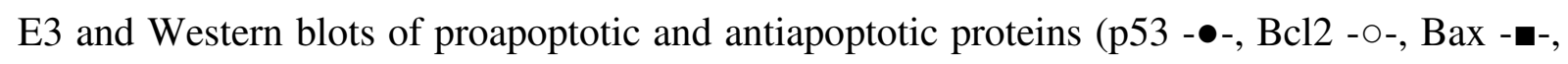




\begin{abstract}
Akt - $\boldsymbol{\nabla}-$, pAkt - $\nabla-$, Mdm-2 - - and NFkB p65 - $\square-)$ were carried out. Control represents untreated cells. Actin was used as a protein control of constitutive expression. Treatments were applied for 13, 19 and 24 hours. The represented values correspond to the mean of three different experiments. All values were corrected to the staining intensity of actin in control cells.
\end{abstract}

Figure 8. Western blot analyses of p53, Akt and p-Akt in DA-1 cells treated independently with E1 extract, E2 extract or methanol-extracted semipurified E3 fraction. DA-1 cells were incubated as described in the Methods Section and Western blots of p53, Akt and pAkt were carried out. Treatments were done at different times (13, 19 and 24 hours). The figure shows a representative experiment.

Figure 9. Western blot analyses of procaspase 3 levels in DA-1 cells treated independently with E1 extract, E2 extract or methanol-extracted semipurified E3 fraction. DA-1 cells were incubated as described in the Methods Section and Western blot of caspase 3 was carried out. The blot shows the region corresponding to the uncleaved procaspase 3 band. Treatments were done at different times (13 and 24 hours). The figure shows a representative experiment. 


\section{REFERENCES}

Allen RT, Cluck MW, Agrawal DK. 1998. Mechanisms controlling cellular suicide: role of Bcl-2 and caspases. Cell Mol Life Sci 54: 427-45.

Barak Y, Juven T, Haffner R, Oren M. 1993. Mdm2 expression is induced by wild type p53 activity. EMBO J 12: 461-8.

Cao QZ, Lin ZB. 2004. Antitumor and anti-angiogenic activity of Ganoderma lucidum polysaccharides peptide. Acta Pharmacol Sin 25: 833-8.

Chang, S.-T, Miles, P. 2004. Mushrooms: cultivation, nutritional value, medicinal effect, and environmental impact. CRC Press

Chen J, Wu X, Lin J, Levine AJ. 1996. Mdm-2 inhibits the G1 arrest and apoptosis functions of the p53 tumor suppressor protein. Mol Cell Biol 16: 2445-52.

Cheung WMW, Hui WS, Chu PWK, Chiu SW, Ip NY. 2000. Ganoderma extract activates MAP kinases and induces the neuronal differentiation of rat pheochromocytoma PC12 cells. FEBS Letters 486: 291-296.

Chiou SK, Rao L, White E. 1994. Bcl-2 blocks p53-dependent apoptosis. Mol Cell Biol 14: 2556-63.

Gottlieb E, Haffner R, von Ruden T, Wagner EF, Oren M. 1994. Down-regulation of wildtype p53 activity interferes with apoptosis of IL-3-dependent hematopoietic cells following IL-3 withdrawal. EMBO J 13: 1368-1374.

Gottlieb E, Lindner S, Oren M. 1996. Relationship of sequence-specific transactivation and p53-regulated apoptosis in interleukin 3-dependent hematopoietic cells. Cell Growth Diff 7: 301-310.

Gottlieb E, Oren M. 1998. p53 facilitates pRb cleavage in IL-3-deprived cells: novel proapoptotic activity of p53. EMBO J 17: 3587-3596. 
Hong KJ, Dunn DM, Shen CL, Pence BC. 2004. Effects of Ganoderma lucidum on apoptotic and anti-inflammatory function in HT-29 human colonic carcinoma cells. Phytother Res 18: 768-70.

Hu H, Ahn NS,Yang X, Lee YS, Kang KS. 2002. Ganoderma lucidum extract induces cell cycle arrest and apoptosis in MCF-7 human breast cancer cell. Int J Cancer 102: 250-253

Hsu MJ, Lee SS, Lin WW. 2002. Polysaccharide purified from Ganoderma lucidum inhibits spontaneous and Fas-mediated apoptosis in human neutrophils through activation of the phosphatidylinositol 3 kinase/Akt signaling pathway. J Leukoc Biol 72: 207-16.

Jiang J, Slivova V, Valachovicova T, Harvey K, Sliva D. 2004a. Ganoderma lucidum inhibits proliferation and induces apoptosis in human prostate cancer cells PC-3. Int J Oncol 24: 1093-1099.

Jiang J, Slivova V, Harvey K, Valachovicova T, Sliva D. 2004b. Ganoderma lucidum suppresses growth of breast cancer cells through the inhibition of Akt/NF-kappaB signaling. Nutr Cancer 49: 209-16.

Li CH, Chen PY, Chang UM, Kan LS, Fang WH, Tsai KS, Lin SB. 2005. Ganoderic acid X, a lanostanoid triterpene, inhibits topoisomerases and induces apoptosis of cancer cells. Life Sci 77: $252-65$.

Lin ZB. 2005. Cellular and molecular mechanisms of immuno-modulation by Ganoderma lucidum. J Pharmacol Sci 99: 144-53.

Lin SB, Li CH, Lee SS, Kan LS. 2003. Triterpene-enriched extracts from. Ganoderma lucidum inhibit growth of hepatoma cells via suppressing protein kinase $\mathrm{C}$, activating mitogen-activated protein kinases and G2-phase cell cycle arrest. Life Sci 72: 2381-90.

Liu X, Yuan J-P, Chung Ch-K, Chen X-J. 2002. Antitumor activity of the sporoderm-broken germinating spores of Ganoderma lucidum. Cancer Letters 182: 155-161. 
Lowe S, Bodis S, McClatchey A, Remington L, Riley HE, Fisher DE, Housman DE, Jacks T. 1994. p53 status and the efficacy of cancer therapy in vivo. Science 266: 807-10.

Lu QY, Jin YS, Zhang Q, Zhang Z, Heber D, Gol VL, Li FP, Rao JY. 2004. Ganoderma lucidum extracts inhibit growth and induce actin polymerization in bladder cancer cells in vitro. Cancer Letters 216: 9-20.

Mayo MW, Baldwin AS. 2000. The transcription factor NF-kappaB: control of oncogenesis and cancer therapy resistance. Biochim Biophys Acta. 1470: M55-62.

Merino JJ, Cordero-Campaña MI. 1998. Molecular bases of the programmed cell death process: implications of tumor suppressor protein p53 and other proteins in the control of cell cycle. Mechanisms of apoptotic action. Invest Clin 39: 323-58.

Messmer UK, Brüne B. 1997. Attenuation of p53 expression and Bax down-regulation during phorbol ester mediated inhibition of apoptosis. Brit J Pharmacol 121: 625-634.

Min, BS, Gao, JJ, Nakamura, N, Hattori, M. 2000. Triterpenes from the spores of Ganoderma lucidum and their cytotoxicity against meth-A and LLC tumor cells. Chem Pharm Bull 48: 1026-33.

Mizushina Y, Hanashima L, Yamaguchi T, Takemura M, Sugawara F, Saneyoshi M. 1998. A mushroom fruiting body-inducing substance inhibits activities of replicative DNA polymerases. Biochem Biophys Res Commun 249: 17-22.

Müller CI, Kumagai T, O'Kelly J, Seeram NP, Heber D, Koeffler HP. 2006. Ganoderma lucidum causes apoptosis in leukemia, lymphoma and multiple myeloma cells. Leuk Res 30: 841-8.

Newcomb EW. 1995. P53 gene mutations in lympoid diseases and their possible relevance to drug resistance. Leuk Lymphoma 17: 211-221.

Miyashita T, Reed JC. 1995. Tumor supressor p53 is a direct transcriptional activator of the human bax gene. Cell 80: 293-299. 
Olmos G, Prieto A, Herráez A, Tejedor MC, Alvarez-Mon M, Diez JC. 2005a. Involvement of Bax, Bcl-2 and caspase -3 in hydroxyurea- or etoposide-induced apoptosis of mouse interleukin-3-dependent lymphoma cells. Anticancer Res 25: 999-1008.

Olmos G, Prieto A, Herráez A, Tejedor MC, Alvarez-Mon M, Diez JC. 2005b. Quantitation of apoptosis induction by etoposide or hydroxyurea in mouse interleukin 3-dependent lymphoma cells. In vivo 19: 455-464.

Palacios C, Gutierrez del Arroyo A, Silva A, Collins MK. 2000. The role of p53 in death of IL-3-dependent cells in response to cytotoxic drugs. Oncogene 19: 3556-3559.

Raisova M, Hossini AM, Eberle J, Riebeling C, Wieder T, Sturm I, Daniel PT, Orfanos CE, Geilen CC. 2001. Bax/Bcl-2 ratio determines the susceptibility of human melanoma cells to CD95/Fas-mediated apoptosis. J Invest Dermatol 117: 333-40.

Shibata A, Nagaya T, Imai T, Funahashi H, Nakao A, Seo H. 2002. Inhibition of NF-kappaB activity decreases the VEGF mRNA expression in MDA-MB-231 breast cancer cells. Breast Cancer Res Treat. 73: 237-43.

Sliva D. 2004. Cellular and physiological effects of Ganoderma lucidum (Reishi). Mini Rev Med Chem 4: 873-879

Sliva D, Labarrere C, Slivova V, Sedlak M, Lloyd Jr. FP, Ho NW. 2002. Ganoderma lucidum suppresses motility of highly invasive breast and prostate cancer cells. Biochem Biophys Res Commun 298: 603-612.

Sone Y, Okuda R, Wada N, Kishida E, Misaki A. 1985. Structures and antitumor activities of the polysaccharides isolated from fruiting body and the growing culture of mycelium of Ganoderma lucidum. Agric Biol Chem 49: 2641-53.

Stanley G, Harvey K, Slivova V, Jiang J, Sliva D. 2005. Ganoderma lucidum suppresses angiogenesis through the inhibition of secretion of VEGF and TGF-beta1 from prostate cancer cells. Biochem Biophys Res Commun 330: 46-52 
Tang W, Liu JW, Zhao WM, Wei DZ, Zhong JJ. 2006. Ganoderic acid T from Ganoderma lucidum mycelia induces mitochondria mediated apoptosis in lung cancer cells. Life Sci 80: 205-11.

Trotter, J. 2004. WinMDI (Windows Multiple Document Interface for Flow Cytometry), version 2.8. Available from http://facs.scripps.edu/software.html

Towbin H, Staehelin T, Gordon J. 1979. Electrophoretic transfer of proteins from polyacrylamide gels to nitrocellulose sheets: procedure and some applications Proc Natl Acad Sci USA 76: $4350-4354$.

Wilasrusmee C, Kittur S, Siddiqui J, Bruch D, Wilasrumee S, Kittur DS. 2002. In vitro immunomodulatory effects of ten commonly used herbs on murine lymphocytes. J Altern Complement Med 8: 467-75.

Williamson EM. 2001. Synergy and other interactions in phytomedicines. Phytomedicine 8: 401-9.

Xie JT, Wang CZ, Wicks S, Yin JJ, Kong J, Li J, Li YC, Yuan CS. 2006. Ganoderma lucidum extract inhibits proliferation of SW 480 human colorectal cancer cells. Exp Oncol 28: $25-9$.

Yeung WH, Lu QY, Zhang Q, Go VLW. 2004. Chemical and Biochemical basis of the potential anti-tumor properties of Ganoderma lucidum. Curr Top Nutraceutical Res 2: 67-77. Zhao HB, Lin SQ, Liu JH, Lin ZB. 2004. Polysaccharide Extract Isolated From Ganoderma lucidum Protects Rat Cerebral Cortical Neurons From Hypoxia/Reoxygenation Injury. J Pharmacol Sci 95: $294-8$.

\section{Ethics}

This work accomplishes all the ethical institutional or national requirements.

\section{Conflict of interest}

The authors declare no conflict of interest with this work. 
DA-1 cells were grown in the conditions indicated in Experimental section in the presence of conditioned medium containing interleukin 3, E1, E2 or E3 represent treatments with Ganoderma lucidum extracts. Etoposide $100 \mu \mathrm{M}$ treatment was used as a control. Different times of treatment are shown by open, filled and striped bars. All the experiments were repeated three or four times and the mean and SEM are plotted. Significance was evaluated using student's t test. The asterisk $*$ indicate $\mathrm{p}<0.05$.

$165 \times 90 \mathrm{~mm}(600 \times 600 \mathrm{DPI})$ 


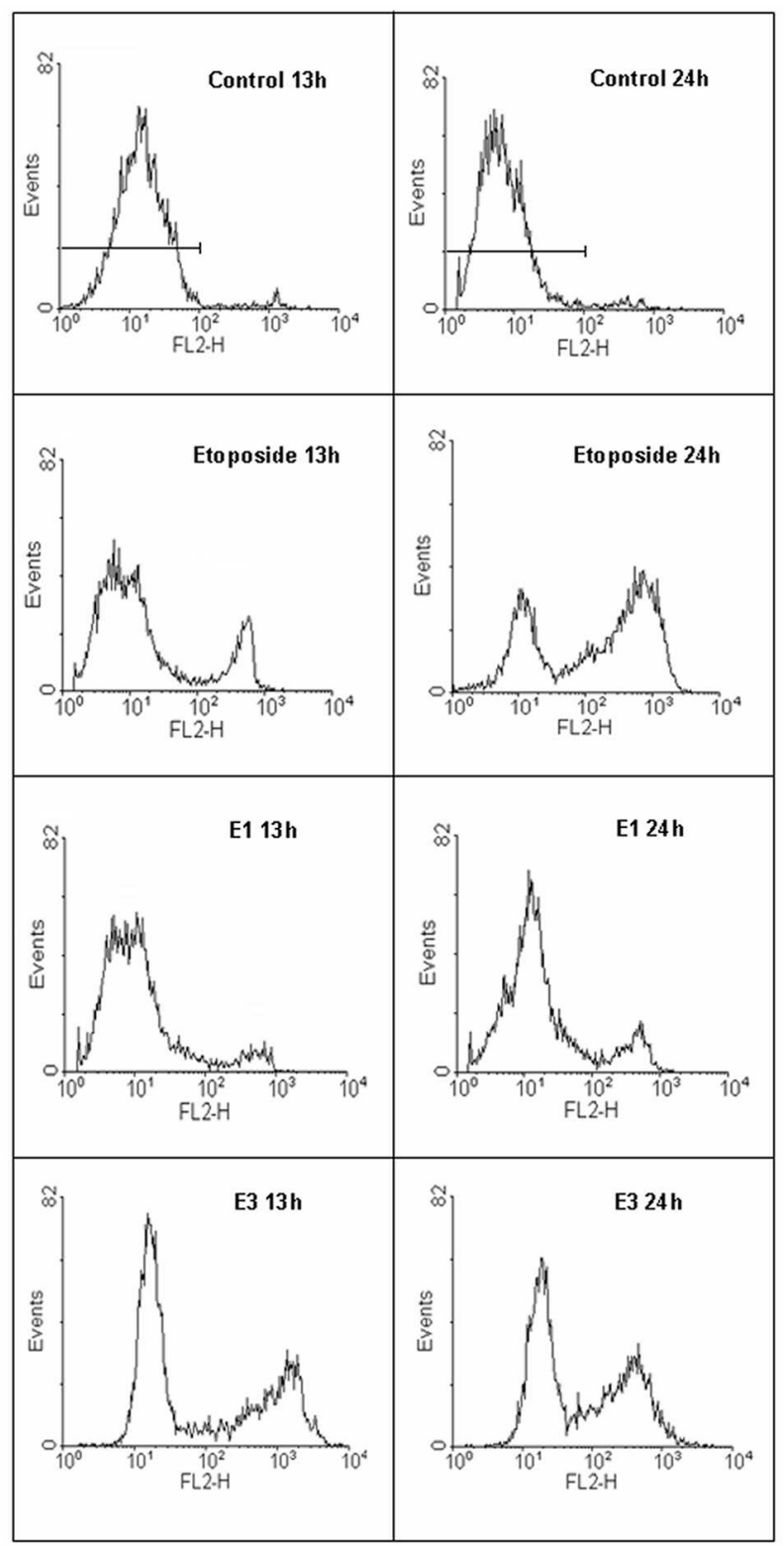

Figure 2. Propidium iodide permeability of DA-1 cells grown in different culture conditions. Cellular viability was measured through propidium iodide permeability. Representative histograms of propidium iodide fluorescence are shown for control cells and cells treated either with $100 \mu \mathrm{M}$ etoposide, E1 extract or E3 fraction from Ganoderma lucidum. $81 \times 159 \mathrm{~mm}(600 \times 600 \mathrm{DPI})$ 
Figure 3. Apoptosis of DA-1 cells induced by extracts from Ganoderma lucidum. The apoptosis induced by treatment with extracts from Ganoderma lucidum was measured by quantifying subdiploid DNA. Different times (13,19 and 24 hours) are shown by open, filled and striped bars. Untreated cells and cells treated with $100 \mu \mathrm{M}$ etoposide are included as negative and positive controls for apoptosis. All the experiments were repeated three or four times and the mean and SEM are plotted. Significance was evaluated using student's t test. The asterisk * indicate $p<0.05$. $165 \times 89 \mathrm{~mm}(600 \times 600 \mathrm{DPI})$ 


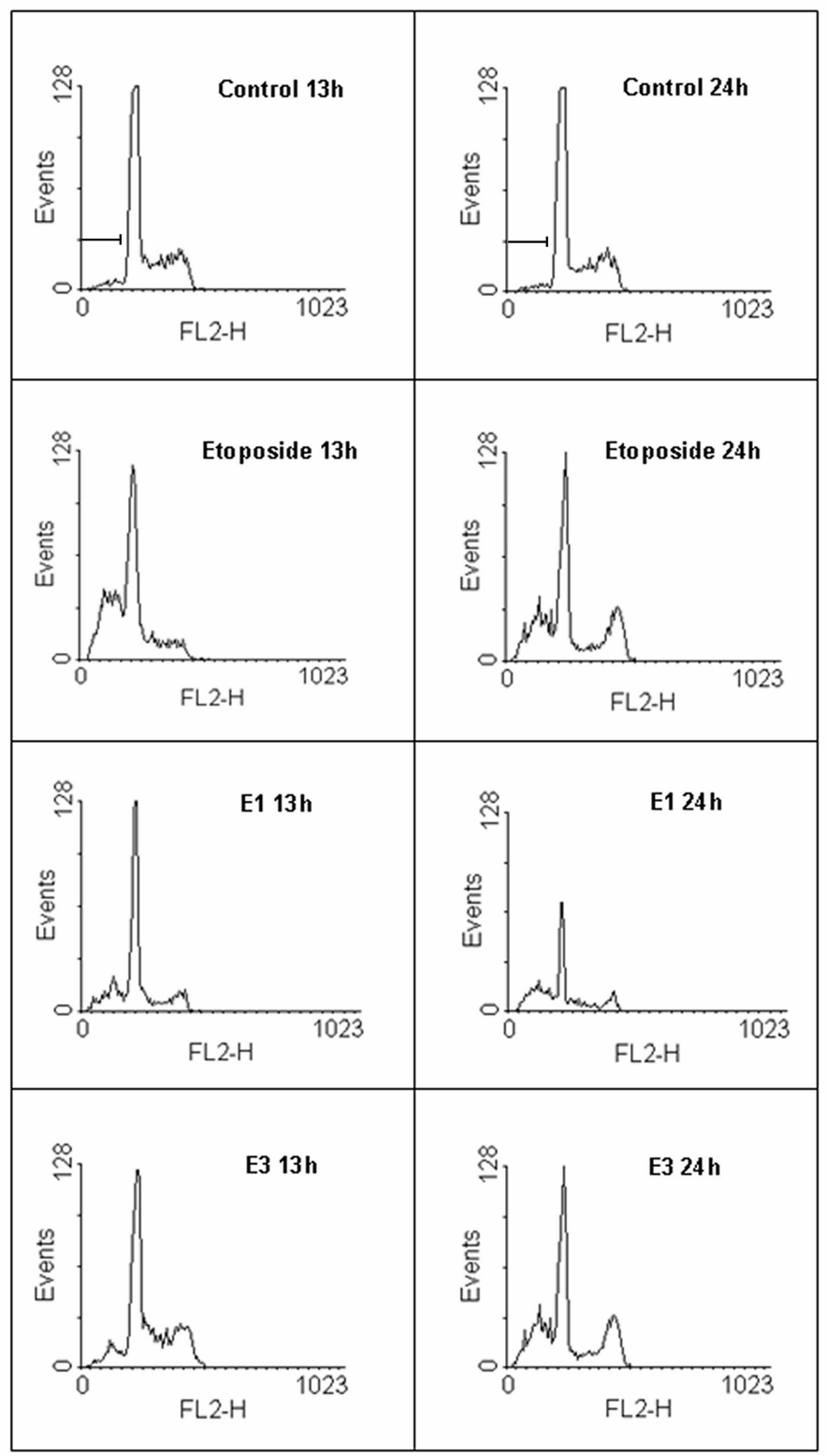

Figure 4. DNA fragmentation on DA-1 cells induced by treatments with different extracts from Ganoderma lucidum. The apoptosis induced by treatment with extracts from Ganoderma lucidum was measured by quantitation of subdiploid DNA. This figure shows representative histograms of the DNA content, measured with propidium iodide, present in control cells and cells treated with 100 $\mu \mathrm{M}$ etoposide, E1 extract or E3 fraction from Ganoderma lucidum after 13 or 24 hours. The number of events versus the intensity of fluorescence of propidium iodide is shown. $81 \times 142 \mathrm{~mm}(600 \times 600 \mathrm{DPI})$ 


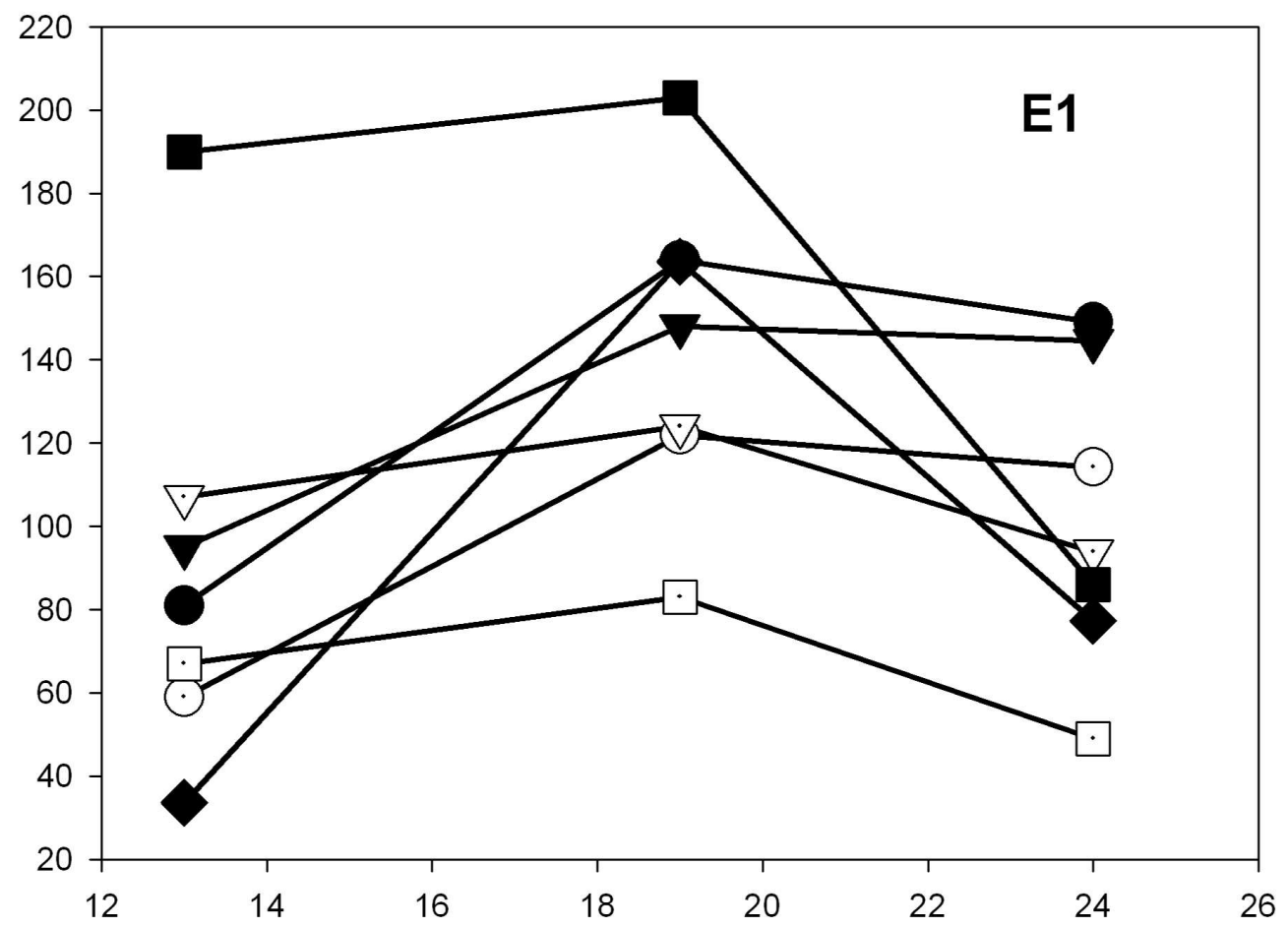

Figure 5. Expression of apoptotic factors in DA-1 cells treated with E1 aqueous extract. DA-1 cells were incubated with E1 and Western blots of proapoptotic and antiapoptotic proteins

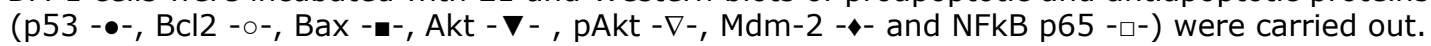
Control represents untreated cells. Actin was used as a control of constitutive expression. Treatments were applied for 13, 19 and 24 hours. The represented values correspond to the mean of three different experiments. All values were corrected to the staining intensity of actin in control cells.

$156 \times 115 \mathrm{~mm}(600 \times 600 \mathrm{DPI})$ 


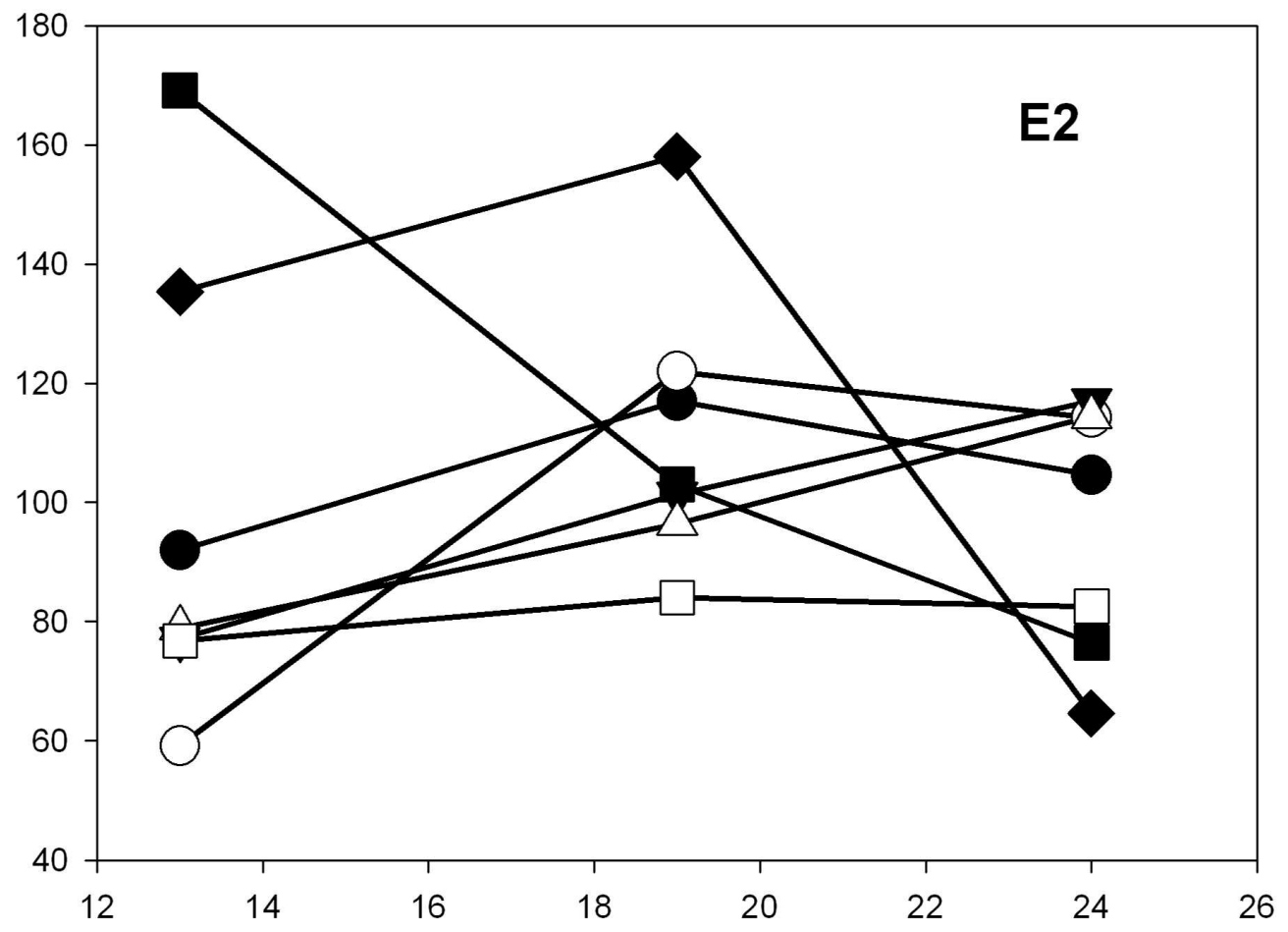

Figure 6. Expression analyses of DA-1 cells levels of apoptotic factors in DA-1 cells treated with E2 aqueous extract. DA-1 cells were incubated with E2 and Western blots of proapoptotic and

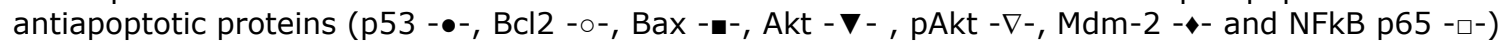
were carried out. Control represents untreated cells. Actin was used as a protein control of constitutive expression. Treatments were applied for 13,19 and 24 hours. The represented values correspond to the mean of three different experiments. All values were corrected to the staining intensity of actin in control cells. $155 \times 115 \mathrm{~mm}(600 \times 600 \mathrm{DPI})$ 


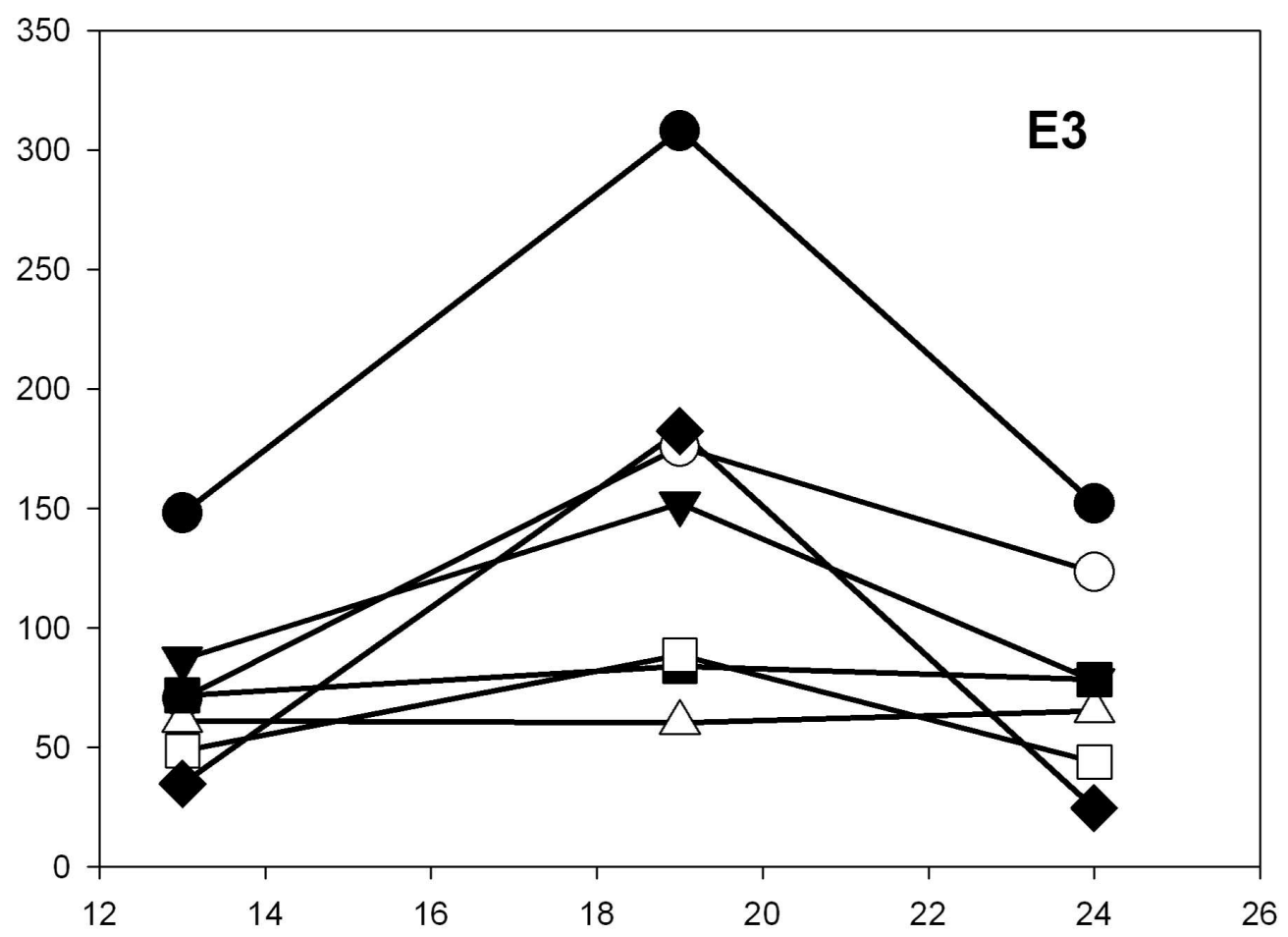

Figure 7. Expression analyses of DA-1 cells levels of apoptotic factors in DA-1 cells treated with methanol-extracted semipurified E3 fraction. DA-1 cells were incubated with E3 and Western blots

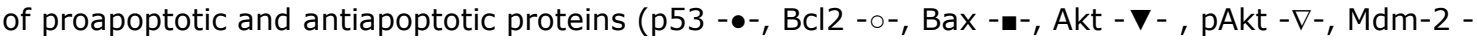
$\checkmark-$ and NFkB p65 - $-_{-}$) were carried out. Control represents untreated cells. Actin was used as a protein control of constitutive expression. Treatments were applied for 13, 19 and 24 hours. The represented values correspond to the mean of three different experiments. All values were corrected to the staining intensity of actin in control cells. $155 \times 115 \mathrm{~mm}(600 \times 600 \mathrm{DPI})$ 
Figure 8. Western blots analyses of p53, Akt and p-Akt in DA-1 cells treated independently with E1 extract, E2 extract or methanol-extracted semipurified E3 fraction. DA-1 cells were incubated as described in the Methods Section and Western blots of p53, Akt and pAkt were carried out. Different treatments were done at different times $(13,19$ and 24 hours). The figure shows a representative WB experiment.

$82 \times 53 \mathrm{~mm}(600 \times 600 \mathrm{DPI})$ 
Figure 9. Western blots analyses of procaspase 3 levels in DA-1 cells treated independently with E1 extract, E2 extract or methanol-extracted semipurified E3 fraction. DA-1 cells were incubated as described in the Methods Section and Western blot of caspase 3 was carried out. The blot shows the region corresponding to the uncleaved procaspase 3 band. Different treatments were done at different times (13 and 24 hours). The figure shows a representative WB experiment. $201 \times 71 \mathrm{~mm}(600 \times 600 \mathrm{DPI})$ 